\title{
Identification of stereotypes in the artistic text
}

\section{(on the basis of Ukrainian, Polish and British realist prose)}

\author{
Vira Burak \\ Ph. D. student, Department of General Linguistics \\ Ivan Franko National university of Lviv, Lviv, Ukraine \\ vira.burak@ukr.net
}

\begin{abstract}
Stereotypes are an extremely complex object of research. Mental construction cannot be static. Old stereotypes slowly change, new ones appear and with the help of various codes (linguistic, cultural, literary) the author encrypts all of this into the artistic text. Besides the existence of linguistically expressed but not linguistically fixed stereotypes in artistic texts, stable stereotypes undergo different modifications of sense and verbalization forms. The ultimate goal of the research is to identify the factors which determine the form and the meaning of stereotypes verbalizers; to carry out a functional differentiation of linguistic signs that refer to these conventional referents in Ukrainian, Polish and British realist prose. Stabilized stereotypes are fixed by nominations of different structural and semantic complexity. Within the limits of the semantic structure of a nomination there is a hierarchy of semantic features: their typicality, frequency of functioning and, hence - stereotypicality - decreases from the center towards the periphery. In the core zone, semantics of a stereotype coincides with the semantics of a prototype. Stereotypes with different degree of conventionality and communicative relevance are explicated in artistic texts with the help of structurally different nominative and communicative units.
\end{abstract}

Indexing terms/Keywords: stereotype, prototype, cognitive reference, artistic text, worldview, verbalization, conventionality, communicative relevance.

Subject Classification: Ethnolinguistics

Type (Method/Approach): Discourse analysis, Literary Analysis.

Language: English

Date of Publication: 2018-06-30

DOI: 10.24297/jal.v9i1.7425

ISSN: 2348-3024

Volume: 9 Issue: 1

Journal: Journal of Advances in Linguistics

Website: https://cirworld.com

This work is licensed under a Creative Commons Attribution 4.0 International License. 


\section{Introduction}

Stereotypes perform a correlative function during verbal communication - they serve as a background for the interpretation of utterances. Stereotypes are an extremely complex object of research as consciousness collective consciousness in particular - is hard to observe. It is regarded that fiction is the manifestation of the collective consciousness. Thus, the dynamic worldview system of a linguistic community can be studied on the basis of specific texts which represent the facts of both language and speech. The majority of scholars view the artistic text as a special sign that denotes one of the possible worlds. In scientific literature, reference of artistic speech is defined as imitated, hanging or as pseudo-referencing, since the author creates a narrator that pretends to speak. An artistic world is shaped by the means of language, so the limit of its irreality is the limit of creative use of semantics. Interpretation of everyday speech is carried out through the extensional semantics of actualized signs which refers to real referents - phenomena that exist in the real world. Information verbalized in the artistic text may have a real referent, however the reference is made not directly towards the object, for example, London, but indirectly - towards the common knowledge of the writer and predicted readers about this city. In that connection, we believe that the artistic text - particularly the linguistic signs actualized within it - makes a cognitive reference to the background knowledge of an ethnic community through the intensional semantics. One of such mental referents is a stereotype. Therefore, stereotypes as the collective experience of a linguoculture act as communicative dominants of artistic text interpretation: they define the priority in the choice of ideas from the cognitive base of knowledge. Adequate decryption of the author's artistic speech requires a certain level of linguistic and cultural competence from the reader. In turn, the role of the writer as a linguistic personality is decisive with respect to how the stereotype will be presented in an artistic text. Each way is conditioned by its communicative purpose. Despite this, the writer has to follow the rules of successful communication. In order to realize the communicative relevance of the text, the author strives to create a language code which will ensure the success of predicted interpretation. Focusing on the predicted reader the writer uses the empathic ability to determine which information is known to the readers. Taking into account that a stereotype is known to all or most of the members of a linguistic community, verbalized information which corresponds to the stereotype is perceived by the speakers as something obvious; and vice versa - information which does not fit into the stereotype has to be explained and outlined by additional speech means. Hence, the writer as a competent native speaker and someone knowledgeable in the culture of his/her epoch profiles the collective experience of an ethnic culture: he/she evaluates which experience has already become conventional and how well-known this or that stereotype is, to determine how many and which linguistic signs are to be actualized so that the interpretation of the artistic text was successful. In this regard, the linguistic study of stereotypes in artistic texts is carried out through the semantic and pragmatic analysis of linguistic signs which refer to stereotypes as to conventional referents. Closely connected theories of reference and semantics underwent considerable changes during the last century. Consequently, the notion of a stereotype in ethnolingustics evolved as well. Now we will examine this problem in detail.

\section{Materials and Methods}

For a long time, a stereotype was understood as a result of collective cognition of a people, correlative with the naïve image of the world; as an objectified and preserved in the linguistic image of the world communicative and life experience of a linguistic community $[10,65]$. From the point of view of the static model of a sign put forward by F. de Saussure [58], reference is made only by those signs that perform a nominative function. And thus, stereotypes certainly have a linguistic expression: they are indicated by nominations. It was this understanding of reference that formed the basis of the first ethnolinguistic studies of language pictures of the world, carried out on the basis of folklore texts [see generally 1, 2, 19 etc.]. Tremendous work was done to catalogue and register the most linguistically fixed stereotypes: Stownik stereotypów i symboli ludowych [8], Slavianskie drevnosti [54], Znaky ukrainskoi etnokultury [69]. Therefore, the studies of linguistically fixed collective ideas about the world represent the static model of a stereotype which is based on the reference of nominations exclusively. Yet, mental construction cannot be static as the dynamism of the psyche predetermines the instability of the coordinate system 'Human being-World'. That is why the static model of a stereotype does not reflect the complete nature of the modeled phenomenon. In this way, it is possible only to describe its structure 
and the state of linguistic expression at a particular synchronic point. Although the means of verbalization will be registered and catalogued, they will remain functionally undifferentiated. Nonetheless, old stereotypes slowly change, new ones appear and with the help of various codes (linguistic, cultural, literary) the author encrypts all of this into the artistic text. Besides the existence of linguistically expressed but not linguistically fixed stereotypes in artistic texts, stable stereotypes undergo different modifications of sense and verbalization forms. As it was repeatedly stated $[3,17,32,43,50]$ : at a current stage of development of linguistics it is not sufficient to answer such questions as What? Where? and When? It is necessary and now possible to look for answers to questions How? and Why? How do stereotypes function in an artistic text? Why some stereotypes are referred to by the units of language, while others - only by the units of speech? How do stereotypes which differ according to the degree of their conventionality and communicative relevance correlate with distinct forms of their verbalization? Why do stereotypes undergo changes differently and how is it reflected in artistic texts? In order to answer these and other questions and perform the functional differentiation of the means of stereotype verbalization in artistic texts, it is necessary to reconsider the starting point - the very notion of a stereotype. The search for the optimal semantic analysis that would effectively decipher culturally and communicatively relevant information continues and has triggered the evolution of views on reference in ethnolingusitics. The research includes the dynamic model of linguistic sign devised by Ch. Peirce [41] and Ch. Morris [38] which involves the subject that codes the interpretation of cognized world in linguistic signs (the author) and in reverse - interprets linguistic signs in speech (the reader). Due to reassessment of the reference system, the semantic theory, too, underwent some changes. Cognitive ethnolingustics saw a real breakthrough with the semantic conception of connotation which takes into account the reference of nominations in the process of communication, where most of culturally determined ideas connected with the use of linguistic signs actually manifest themselves $[27,28,45]$. Thus, the extension of a sign equals the totality of its possible intensions, i.e. the meaning of the sign comprises all of the possible senses of its usage. The shift of the emphasis towards the reference in speech opened a new prospect of researching the collective worldview of people from different epochs, whose picture of the world is not as naïve as it is depicted in folklore texts. It is also recognized that both nominative and communicative units make references - in particular, they refer to life experience of speakers [31]. It expanded the limits of ethnolinguistic analysis of stereotypes which enabled to include artistic texts as a material for research.

\section{Formulation of the objectives}

First of all, it is necessary to establish the criteria of identification of stereotypes in an artistic text; to find out what is the correlation between language and speech means of stereotype verbalization that are at different stages of formation. The ultimate goal of the research is to identify the factors which determine the form and the meaning of stereotypes verbalizers; to carry out a functional differentiation of linguistic signs that refer to these conventional referents in Ukrainian, Polish and British realist prose. In order to avoid overgeneralization during the presentation of the material we will look at the theoretical part using the example of a specific fragment of experience of compared linguocultures in the second half of the XIX century, in particular - the ideas about family.

\section{Results and Discussion}

\section{Types of collective experience and forms of their verbalization}

The communicative approach in ethnolinguistics is in the process of formation. Thus, the methodology of the research of ethnic consciousness on the basis of creative texts has not been fully developed, so there is no universal method of stereotype identification in an artistic text. From the new point of view opens the perspective of researching stereotypes dynamically as mechanisms of cognitive process of an ethnic group and as "part of multilevel system of social communication" [11:259]. Taking into account that a human being cognizes something new relying on the information already known, all the fragments of collective experience are closely connected and interdependent. That is why we believe that stereotypes are not isolated mental structures, but that they form a dynamic network of collectively objectified experience. Information accumulated by means of 
stereotypes is presented not just as a sum of useful knowledge, but as an experience organized in a particular way which, owing to its structuring, can be passed on to the next generations [48:193-194]. The most important fragments of this network are indicated by various nominations with an open semantic structure. Hence, the functioning of stereotypes is conditioned by phenomena of conceptualization, categorization and verbalization of the most communicatively relevant collective experience of a linguistic community. Because stereotypes "on the one hand, perform the selection of information that comes to the subject from the outside and, on the other hand, structure the internal experience and prepare the information for furthering and processing in the deeper levels of consciousness with the aim of fixing it in memory" [51:177], they are often correlated with prototypes. To establish the criteria of identification of stereotypes in an artistic text, we need to characterize this phenomenon and also distinguish it from other correlated phenomena. The theories of stereotype and prototype emerged in the 70s of the XIX century as an alternative to the classical theories of reference (G. Frege, R. Carnap, B. Russell), categorization (Aristotle) and meaning (F. De Saussure, J. Trier, L. Weisgerber). We agree with G. Lakoff's statement that in the works of H. Putnam - the founder of the linguistic research of stereotypes - "the description of stereotypes sometimes was very close to the theory of prototypes, however, despite this, his special term "stereotype" does not completely correspond to a prototype." The problem of distinction between stereotypes and prototypes is connected with both phenomena representing typical, conventional, collectively objectified and verbalized experience of a linguistic community. Scientific literature views the notions of stereotype and prototype in relation of: identity [34], complementarity [22, 49, see generally 67] and inclusion [24]. Proceeding from the idea of Polish researchers that a prototype is nothing but a stereotype's core, and a stereotype "can move closer to and away from the core", we think that the model of collective experience possesses the core-periphery structure with the prototype in the center surrounded by stereotypes at different stages of formation. Hence, the core zone includes the most typical and exemplary features of an object or phenomenon. As typicality and frequency of their usage in communication decreases towards the periphery, the degree of conventionality and objectivity of experience decreases closer to periphery as well: it becomes more occasional and subjective. A formed stereotype is fixed by a nomination, since it is "a mental structure which has already been arranged in the human consciousness (ethnic consciousness - V. B.), and serves as its operational unit assigned to a particular experience rubric" [32:235]. As every nomination represents a generalized idea about the class of objects (denotation), typical experience of a linguistic community, therefore, is the result of categorization. Taking this into account, we are of the opinion that nominations verbalize stabilized areas of an ethnic concept-sphere - prototypes. The process of categorization is preceded by conceptualization which is the cognition of separate objects and phenomena. The basis of conceptualization consists in identification of repeated features of an object or phenomenon in different functional situations as seen by a subject. Hence, typical experience of interacting with an object or phenomenon is formed in the process of conceptualization. That is why a stereotype is "an idea about an object which formed within a particular collective experience and determines how this object looks like, acts, is perceived by a person, etc.; at the same time, this idea is embodied in language, is accessible through language (and speech - V. B.), and belongs to collective knowledge about the world" [13:15]. Stereotyping as the process of selection and creation of a hierarchy of features of a cognized object or phenomenon covers everything that a linguistic community observes. In traditional (folklore) texts "stereotyping can be recognized via analysis of frequency of an object's feature in different utterances (statistical analysis), through the fixing of this feature in language (analysis of derived words, metaphors, phraseology and sayings), and via analysis of the construction rules of a semantically connected text" [7:366]. That is to say, the method of identification of stereotypes from clichéd (term of R. Tokarski) folklore texts is the analysis of semantics of stereotype nominations in different in volume linguistic contexts: 1) internal form of a nomination; 2) figurative meaning of a word; 3) derivatives; 4) phraseological units; 5) sayings; 6) semantic structure of composite sentences: negative and causal ones [13:170]. According to L. Krysin, stereotypes function in any oral or written text, i.e. they are expressed in speech, and subsequently can become fixed in a linguistic system. The researcher expands the list of verbalizers by adding: 7) comparative clauses; 8) genitive and attributive combinations; 9) utterances with quantifiers such as all, every, any, etc.; 10) utterances with modal adverbs such as indeed, really, surely, etc.; 11) utterances with evaluative adjectives such as interesting, clear, vague, etc.; 12) implicatures [30:452-454, qtd. in 68:24]. Thus, we singled out two types of collective experience: 1) prototypes, which are formed as a result of categorization; their verbalization is actualized through extensional semantics of nominations and is correlated with a linguistic 
paradigmatic image of the world; 2) stereotypes, which are formed in the process of conceptualization; they are explicated by intensional semantics of actualized nominations in speech, therefore we correlate stereotypes with a syntagmatic image of the world (term of Kiklewicz, 25:337). And so, stereotypes play the role of means of prototype formation (generalization of particular typical experience to the level of abstract typical experience of a linguistic community). Undoubtedly, only actualized nominations, which make reference to more or less fixed stereotypes of a specific fragment of collective experience, function in an artistic text. However, by conducting frequency analysis of actualized semantic features of this or other nomination it is possible to describe a prototype of a nominated object or phenomenon. Hence, having outlined the nature of a stereotype and distinguished it from a related phenomenon - a prototype - we now move forward to formulate the criteria of identification of stereotypes in an artistic text.

\section{Verbalization of individual and collective experience in an artistic text}

The problem of identification of linguistic signs that make reference to a stereotype in an artistic text is connected with the postulate of literature originality, and so - with the creativity of the author's artistic speech. An artistic text is created by a linguistic personality that is a competent member of a certain culture, and is addressed mainly to other people belonging to this linguistic community. The writer makes use of linguistic signs and his knowledge about the real world in a creative way, in order to realize his/her own intentions. J. Bartmiński points out that "one of the ways to use stereotypes in an artistic text is «to play» with them, attempt to break them, ridicule them to catch the reader's attention", however, "literature can stabilize and preserve stereotypes, continue their functioning" [6:8]. According to Yu. Lotman, the interpretation of an artistic text is the result of a struggle between the reader and the author who tries to impose his/her views onto the former [37:348]. All the information that is transmitted by an artistic text has come through the lens of the author's individual point of view. The creative reflection of reality is connected with the author's subjective experience and the reconsideration of the collective experience of an ethnic community. Hence, to develop the mechanism of stereotype identification in an artistic text, it is necessary to differentiate between individual (subjective) experience of an author and collective (objectified) experience of a collective community. The author's experience is a fragment of collective experience of a people, so they are not in opposition, but in the relation of 'part-whole'. The means of identification of individual and collective experience verbalization in an artistic text is the category of point of view. The writer's subjective experience in an artistic text is manifested through the opposition of his/her own point of view to the established collective view on different phenomena of reality. Thus, having formulated the criteria of distinguishing between the author's and social viewpoints, it would be possible to outline the limits of stereotype verbalization in an artistic text. Stereotypes would correlate with a collective point of view which is based on typical and objectified experience of a linguistic community. However, the conditions and rules of artistic communication deprive the writer of the obligation of being true. According to J. Searle, within the limits of "a language game of literature" the modality of artistic fiction is allowed for, so the author can violate the maxims of cooperation (invent the things he tells about), without any communicative deviations [61:78]. Hence, the author's individual point of view does not have to be supported by his subjective experience which is different from collectively objectified experience of a linguistic community. It is also necessary to take into account the fact that collective experience presented in an artistic text is, first of all, an abstract generalization made by the writer. For instance, the village of Lipce with all of its people and everyday life described by W. Reymont in his novel The Peasants has never existed, but, at the same time, according to literary critics, resembles thousands of Polish villages at the turn of XIX century [47:288-289]. However, "it is an artistic text not being a reality that makes it want to approach reality. Subsequently, at first, a measure of conventionality is set, some primary instability, and then there comes the struggle with it - the emphasis on similarity" [37:124]. The category of viewpoint "rests on acquired earlier perceptive and cognitive experience" [14:157]. Therefore, a collective viepoint is formed on the basis of objectified experience, and an individual viewpoint is formed on the basis of subjective experience. (see Scheme 1). 


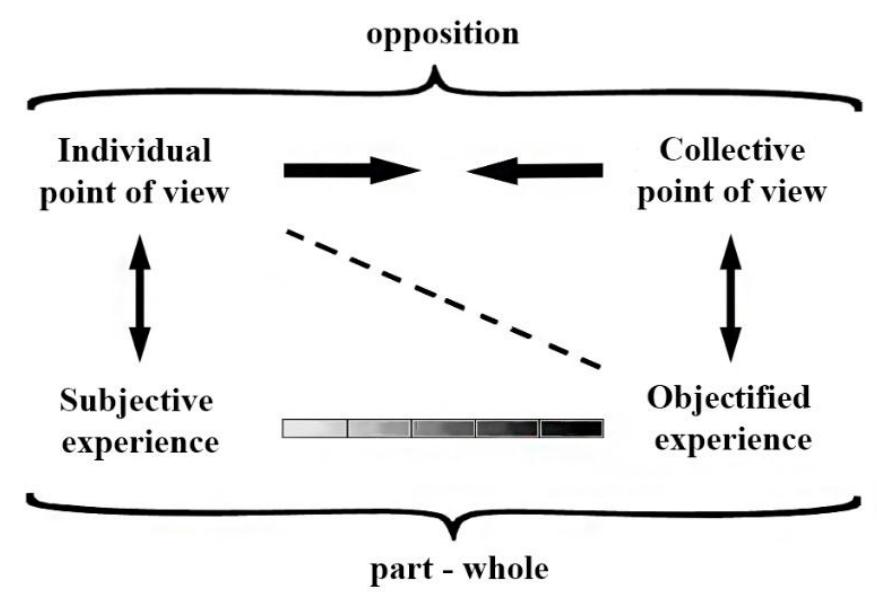

It is important to take into account the fact that the point of view on something can exist only when we are talking about a formed fragment of experience (subjective or objectified). Hence, through the research of the category of viewpoint in an artistic text only the most fixed stereotypes identical to prototypes can be revealed. As subjective and collectively objectified experience are correlated in a complementary way, the more they coincide - the less author's individual viewpoint is opposed to the collective viewpoint of an ethnic community. The category of the point of view is closely connected with the category of evaluation: "it should be so" (positive evaluation), "it should not be so" (negative evaluation). Thus, the main condition for the individual and collective viewpoints on a stereotype to coincide is the identical evaluation of a particular experience fragment. According to W. Chlebda, we tend to think that a stereotype is a physiological-mental adaptive mechanism which has formed during human evolution with the aim of protection from the instability of environment, and helps master and systematize perceptive and cognitive experience and operate it with the help of a sign system - linguistic system in particular [16:31-41]. Therefore, we treat stereotypes - which there are distinct either identical or opposing individual and collective points of view on - as stable collective experience. If the viewpoints of an author and an ethnic community are the same regarding the stereotype, it is depicted in an artistic text without changes and has a positive or negative evaluation. We assume that the depiction of a stereotype with a positive evaluation in a text is conditioned by the fact that such an experience helps people navigate in the world, makes life easier and better. A writer creates contexts which refer to a positively evaluated stereotype to achieve a perlocutionary effect: strengthen this collective experience and impose such a behavioral model onto readers. One of the examples is an image of a typical mother created in Ukrainian, Polish and British realist prose - 'a woman who gave birth to a child, loves him/her despite everything and cares for him/her by all possible means.' Actualized linguistic signs transmit pragmatic sense: such actions very often (always) have positive effects on an individual and the society, so it is worth acting in the same way. Introduction of a negatively evaluated stereotype is made only with the aim of reasoning of the promoted behavioral model with a positive evaluation. For instance, in the novel Nad Niemnem by E. Orzeszkowa a context was created, where mother's behavior is not typical: the woman gave birth, loves her children, but she did not raise any of them because she prioritizes men: she always finds a new husband after the previous one dies. "A koniec taki, że pani Starzyńska masz dwoje dzieci i żadnego sama nie wyhodowataś... W mgnieniu oka spracowana i sucha ręka Starzyńskiej oparła się na jej kłębie. Cieńszym trochę niż wprzódy głosem odkrzyknęła: - Nie wyhodowatam, a najśliczniejsze ze wszystkich mam... Owszem! I zaniosła się od śmiechu. - Jak ku-kaw-ka! - z ironiq zaśpiewała znowu Fabianowa» [119-121]; "Jana matka znów Siemaszczanka z Siemaszek, tak jej zaś wypadto, że aż w czterech okolicach życie swoje pędzita: najpierw w ojczystej, czyli w Siemaszkach, potem w Bohatyrowiczach, gdy za Jerzego wyszła, potem za drugim mężem w Jaśmontach, a na ostatku, za trzecim, w Starzynach. - Nie wiadomo, czy to już ostatni mąż $i$ ostatnie jej osiedlenie - żartobliwie znowu zauważyt. - Bo mnie się zdaje, że gdyby dziś owdowiata, to by za rok poniosta sie jeszcze za czwartego!» [154]. Such actions of the mother are evaluated negatively by the author and society, as their consequences can have a bad influence on children and afterwards - on other people. According to W. Lippmann, only leaders can think in a not stereotypic way, have extraordinary 
views on the world and, thus, create new or change old stereotypes (Lippmann). Apart from political leaders, such people also include cultural figures - writers in particular. While describing occasional phenomena writers embody modifications of existing stereotypes. On the level of semantic macrostructure in Ukrainian, Polish and British realist discourse of the $2^{\text {nd }}$ half of the XIX century a negative image of unhappy marriage of convenience was created. It is opposed to a happy marriage based on love through a system of author's evaluations. In Polish and British realist prose a plot is repeated, where, because of love, contracted marriages are unequal ("The Doll" by B. Prus, "Nad Niemnem" by E. Orzeszkowa, "Jane Eyre" by Ch. Brontë, "Vanity Fair" by W. Thackeray). Ukrainian cultural norm of this epoch counts such a deed as an unreal one, because Ukrainian writers model the situation with unequal marriage only as a bright prospect, possible and desirable development (P. Myrnyi "Khiba revut voly, yak yasla povni?", O. Kobylianska "Zemlia"). The creation of new non-standard contexts is accompanied by occasional use of linguistic signs. Hence, the criterion for the identification of stereotypes which the author considers harmful is the existence of text connotations in semantic structures of actualized nominations. According to the theory of internal motivation of semantic features and the theory of semantic irradiation, the semantic space of a stereotype in an artistic text has a nucleus-periphery model. Therefore, we determine the degree of occasionality by applying the method of semantic beaming that allows us to set closer and further text connotations of the actualized signs [53, qtd. in 55:16]. Hence, one of the tactics of drawing the community's attention to an urgent social problem of concluding a marriage of convenience was the creation of a context by W. Reymont, where the semantic structure of the lexeme macocha - 'father's wife from the second marriage, mother-in-law' was supplemented by the text connotation 'stepson's lover'. The intensity of the plot in the novel The Peasants is achieved by the fact that a young girl - abiding by her mother's desire - marries an old widower and becomes a mother-in-law of her true lover, whom she either could not marry, since he was long married and had three children, or did not want to marry, because, as of then, he did not inherit his father's property. Thus, by creatively rethinking the collective experience, writers give their own evaluation to different social phenomena and try to convey their individual points of view - often, to change an outdated stereotype which has a negative impact on peoples' lives. In this case, an indicator of effectiveness of verbal influence may be the sociological researches on the institution of family [20], which attest the transition from a patriarchal family to an emotional family that took place in the societies under comparison. This was a result of the initiation of practice to marry not only for economic or dynastic reasons, but more commonly - because of the feeling of love between the partners and the passing of this love to children. Thus, by modeling a possible world and applying different tactics of verbal influence, a writer realizes the utilitarian function of literature and embodies his/her communicative purposes - particularly, changes stereotypes.

Thus, all information coded in an artistic text is more or less stereotypical. The degree of stereotypicality is directly proportional to the degree of conventionality of collective experience of a linguistic community. The verbalization of formed stable stereotypes is realized through the actualization of linguistic signs in typical contexts. The presentation of a stereotype in an artistic text without changes is possible on the condition that author's and collective evaluation of a described phenomenon coincides. Stereotypes which have a positive evaluation are introduced with the aim of fixing this experience and imposing such a behavioral model on the readers. In their turn, negatively evaluated stereotypes are actualized in artistic texts in order to reason the promoted behavioral model. Stable stereotypes with different viewpoints of an author and an ethnic community on them can be identified by occasional semantics of actualized linguistic units in non-standard contexts. Therefore, with the help of pragmatic analysis of the categories of viewpoint and evaluation of different fragments of linguistic community's collective experience it is possible to identify only formed stable stereotypes. However, it is not sufficient to identify less formed stereotypes. As a result, we need to pay attention to the factors that are more closely related to the phenomenon under research.

\section{Semiotic criteria of stereotype identification in realist prose}

Despite the existence of creative freedom in literature, a writer is limited by the conventions of semiotic systems with the help of which he/she creates and transmits his/her message. So, besides an artistic text making a double reference (to both real and fictional worlds), the conditions of this reference are determined by linguistic, cultural and literary codes. The functioning of stereotypes in an artistic text is conditioned by objective modality which 
is determined by a literary style $[12,53]$. Realist style, in particular, establishes the principle of faithfulness to the objective reality [21:573-575], so it implies the actualization of linguistic signs in the most conventional meanings which create the most faithful depiction of the world. Thus, actualized linguistic signs in realist prose make reference more to the collective experience of a linguistic community, than to the author's individual experience. Realist writers purposefully describe actual and fixed stereotypes in their texts. Thus, in realist prose the limit of creativity is the depiction of occasional, yet potentially possible phenomena and situations; and accordingly the use of linguistic signs in non-standard, but still understandable contexts. In this way, the literary code which is realized in the style, genre and elements in and outside the plot greatly influences the features of functioning of the stereotypes that have not been fully formed in artistic texts, but at the same time it is not the main criterion of their identification and studying.

\section{1. Semiotic structure of an artistic sign: reference to a stereotype}

Stereotypes have a status of linguocultural fusions (term of S. Ivanova, 23). It is natural, since, according to Yu. Lotman, language is a primary system of coding and literature is a secondary one [37:79]. Thus, the most important criterion of stereotype identification in an artistic text is the distinction of the means of their verbalization. The notions of the literary style of the epoch and the artistic style of the literary language are closely interconnected. As E. Vereshchahin put it, "through the linguistic taste of an epoch a text represents the face of that time" [66, qtd. in 23:126]. The style of literary language in ethnolingustics is interpreted as "a system of selection of linguistic means in the process of the derivation of the text $\langle\ldots\rangle$ a peculiar sieve which regulates the selection of lexis, grammatical forms and constructions" [Miko 1970, qtd. in 12:321]. J. Bartmiński believes that colloquial style - which corresponds to the everyday rationality of a native speaker - is the basic and central one among other styles of literary language. Hence, the artistic style emerges as a result of the creative use of the colloquial style. That is, artistic meanings of linguistic signs do not differ from their everyday meanings. However, they typically have a more complex semantic structure because of the actualization of potential semantic features in non-standard contexts. The semantic structure of linguistic signs in a text is modified through the actualization of potential semantic features that can: 1 ) correspond to the phenomena of reality; 2 ) embody the communicative intention of the author. R. Tokarski singles out three types of sematic features in the structure of artistic signs that correspond to collective experience with different degrees of conventionality and objectivity. Hence, designation (or, denotation) is the semantic core of a sign, systemic connotation is the zone around the core and text connotation is the periphery [63:233]. Denotative features are the most conventional and integral in the meaning of a nomination. Systemic connotations are optional and depict cultural ideas associated with this sign. According to K. Pisarkova, "all stereotypes are equivalent to semantic (systemic - V. B.) connotation" [42:6, qtd. in 29:35]. Text connotations constitute an open system of semantic features which "cannot be subjected to verification through formal procedures, as they depend on the viewpoint (of the author - V. B.) of a specific text, all the texts of the author, literary group." Hence, the typicality of semantic features decreases from the center towards periphery, as does the frequency of their functioning in contexts. For instance, in the analyzed texts the more typical experience - that a mother raises her child more often than not - is verbalized. Thus, through the establishment of the hierarchy of features in a semantic structure of a nomination it is possible to reveal which notions within the limits of a particular fragment are more stereotypical and which are less. Now we move on to describe the correlation between language and speech means of stereotype verbalization in artistic texts.

\subsection{Language and speech means of stereotype verbalization in artistic texts}

The fixing of a particular fragment of experience in society does not necessarily mean that it is fixed in language, however, there is a reverse rule: something that is fixed in language is also fixed in society [7:373]. Basing on the idea of N. Tolstoi about the isomorphism of language and culture we believe that stereotype verbalization at different stages of its existence is realized through the semiotic mechanism of stabilization of language meaning and form. According to J. Bartmiński, the process of stereotype verbalization consists of several phases. At each stage of its formation a stereotype obtains communicatively relevant meaning and form of expression. Since "the meaning of a sign is inseparable from the form and the particular state it is expressed in $\langle\ldots\rangle$ in this case 
we talk about both deep ambivalence and mutual motivation" [40:45]. The stabilization of semantics and form of stereotype verbalizers naturally occurs together with the stabilization of collective experience. The researcher distinguishes three phases: 1 ) the phase of referring to a stereotype without the stabilization of meaning and form (an utterance that requires interpretation of extralinguistic knowledge; 2) the phase of meaning stabilization without the features of formal-linguistic fixation (an utterance that can be interpreted through linguistic code); 3) the phase of meaning and form stabilization (fixed verbal formulas). There are no other phases distinguished by the ethnolinguist, but as we have mentioned earlier, the semantics of a formed stereotype in the core zone coincides with the semantics of a prototype, so such a unit of collective experience is fixed by a word. In connection with this, we are of the opinion that it is sensible to distinguish the fourth phase of stereotype verbalization - the phase of meaning and form conservation which is realized by the means of lexical nomination. According to E. Kubriakova, "the depiction of one situation with the help of different nomination means is conditioned by the fact that it is described with different degrees of concretization" [33:78]. The longer the construction of a nomination, the more specifically it conveys the content, and vice versa - the shorter the nomination's construction, the more "hidden semantic components" [33:69] it contains. Respectively, unstable collective experience requires syntagmatically complex nomination, and with each next phase of stabilization syntagmatically simpler nomination. Given that stereotype verbalization in an artistic text is limited by communicative implicatures which can have one or several ways of interpretation, we distinguish two stages of the first phase: 1.1) implicatures which can be interpreted in several way; 1.2) implicatures with one way of interpretation. Within the second phase we distinguish two types of utterances with stabilized content, so we distinguish two stages as well: 2.1 ) semantically bound sentences; 2.2 ) maxims. Similarly (two types of verbal formulas), we divide the third phase into two stages: 3.1 ) semantically bound word combinations; 3.2 ) phraseologisms. Words according to their structure can be simple and derivatives, so within the fourth phase we distinguish two stages: 4.1) conservation of meaning and form in a derivative; 4.2) conservation of meaning and form with the help of the most arbitrary linguistic sign - a simple word. According to Y. Sternin, the unit of language has a twofold character: concerning the object of nomination it acts as a nomination unit, and in a speech act - as a communicative unit [59:6]. Depending on a function (nominative or communicative) which is performed by multistructural linguistic signs in artistic texts we will treat them as nominative or communicative units. However, it is characteristic of some linguistic signs to possess typically nominative or typically communicative function. At every second stage of the four phases of stereotype verbalization collective experience has already undergone the process of stabilization, thus, the typical function of these verbalizers (implicatures with one way of interpretation, maxims, phraseologisms and simple words) has become a nominative one. According to W. Chlebda, stabilized linguistic forms are adjusted to kinetic physiological and mental skills (i.e. articulation and association), so they should be considered stereotype nominations, since these signs are taken out of memory as ready-made constructions. In the case of the first stages of the four distinguished phases, collective experience has not been stabilized yet. Thus, its verbalization occurs only through the signs that are generated in speech each time (implicatures with several ways of interpretation, semantically bound sentences, semantically bound word combinations and derivatives). As for a typically communicative function of complex semantic units (forms of implicatures) and sentences, there is no doubt. It should be specified what we mean, when we talk about the communicative function of semantically bound word combinations and derivatives. For example, a fragment of collective experience - the notion of 'a mother who raises children without a father' in the analyzed artistic texts is verbalized by word combinations with variable components: одинока мати, самотня мати - 'a single mother, a lonely mother' (there is no stabilized form, synonyms are available). Likewise, there are parallel names of a relative formed from a single source, yet with the help of synonymic word-building formants, e.g. nomination сестрична/-іниця/-івниця/-інка - 'а nіесе - sister's daughter' [Hrinchenko 4:117]; siostrzenica/siostrzanka - 'a niece, sister's daughter' [Doroszewski]. In this case, the cultural meaning is created in a syntagmatic chain of subsigns. The same subsign in a different formation can express a distinct cultural meaning while having the same word-building meaning $[15: 88$, see also $5: 19$ ). However, in later dictionaries only a productive (stabilized) version of a derivative was mentioned, which should be regarded as a typically nominative unit. Thus, nominations verbalize stabilized stereotypes, and communicative units verbalize stereotypes in the process of formation. Stereotypes are stabilized at a phase that corresponds to the stage of communicative relevance of a given collective experience fragment. For instance, the notion of 'a girl who is allowed to marry' in Ukrainian realist prose of the $2^{\text {nd }}$ half of the XIX century 
is nominated by the lexeme відданиця [60:98, 39:15, 155], in Polish - by a bound word combination "panna/dziewczyna/córka na wydaniu" [44:0, 35, 51; 47:5], and in British - by a bound sentence "...a young lady who is of age..." [62:298]. Hence, each of the compared linguocultures possesses an outlined collective experience. However, the form of the verbalizers of this stereotype in the mentioned languages indicates that as of the $2^{\text {nd }}$ half of the XIX century for Ukrainians it was a more important experience, than for the Poles, and a much more important one, than for the Britons. Polish linguist Ja. Anusiewicz, while comparing the semantics of a free, bound and phraseologized word combinations (e.g. white wall, white wine, white sport = tennis) comes to the conclusion that according to the degree of arbitrariness these linguistic signs are not equal, and the connection of their form and meaning becomes stronger in the mentioned order [4]. Thus, we assume that from the first to the fourth phase of stereotype verbalization the strengthening of verbalizer arbitrariness takes place. Despite this, the degree of arbitrariness correlates with the degree of verbalizer syntagmatic complexity of a stereotype. The more complex the verbalizer's form, the less arbitrary it is. And vice versa, the simpler the form, the more arbitrary this sign is. Weak arbitrariness proves that a sign is used in a possible but unstable context (a white wall can be black, red, etc.). Strong arbitrariness of a sign means that it is always or frequently used in the same context (a white sport is always tennis). Hence, arbitrariness and structural complexity of the form and meaning of stereotype verbalizers are the main criteria of both their functional differentiation and identification of stereotypes at different stages of formation.

\section{Conclusions}

To sum up, all the information coded in an artistic text refers more or less to stereotypes. An individual and collective point of view can be formed only with regard to stable stereotypes. Thus, by the opposition or coincidence of the viewpoints of the author and the society on some specific experience in an artistic text it is possible to reveal only stable and formed stereotypes. Stabilized stereotypes are fixed by nominations of different structural and semantic complexity. Within the limits of the semantic structure of a nomination there is a hierarchy of semantic features: their typicality, frequency of functioning and, hence - stereotypicality decreases from the center towards the periphery. In the core zone, semantics of a stereotype coincides with the semantics of a prototype. Stereotypes with different degree of conventionality and communicative relevance are explicated in artistic texts with the help of structurally different nominative and communicative units. The scalarity of the model of stereotype verbalization in artistic texts is determined by the four interdependent factors: 1) conventionality; 2) communicative relevance; 3) structural complexity; 4) arbitrariness. In Ukrainian, Polish and British realist prose some stereotypes are more formed and some are less. This is connected with the hierarchy of values, as only the knowledge that is important to a person and his/her activity is fixed in collective consciousness. Moreover, something that is topical for one ethnic culture may be irrelevant to another. The more important some experience is for storage and exchange of information, the more frequently it is used in communication (artistic texts), and the less number of signs is used to verbalize it. Since the economy principle in language determines that the more formed a stereotype is, the more structurally simple verbalization it has, and its arbitrariness is maximal.

\section{References}

1. Ahapkina, Tatiana (red.), 2013, Slavianskaia etnolynhvystyka (Slavic ethnolinguistics). Byblyohrafyia (bibliography), izd. 4, Moskva. Print.

2. Ajdacić, Dejan, 2006, Etnolingwistyka w Serbii, „Etnolingwistyka” 18, s. 67-75. Print.

3. Alefyrenko N. F. Sovremennye problemy nauki o yazyke (Modern problems of the science of language). Moskva. 2005. - 416 s. Print.

4. Anusiewicz, Janusz. Problematyka językowego obrazu świata w poglądach niektórych językoznawców i filozofów niemieckich XX wieku. [w:] "Czerwona Seria" Instytutu Filologii Polskiej UMCS; t 12.- Lublin, 1999. s. 261-289., 297 s. Print. 
5. Anusiewicz, Ja. Dąbrowska A., Fleischer M. 一Językowy obraz świata i kultura : projekt koncepcji badawczej (Intertextuality in the Ukrainian Political Discourse).II Językowy obraz świata i kultura. Wrocław, 2000. 11-44. Print.

6. Bartmiński J. Stereotypy mieszkają w języku. Scriptores Scholarum R. 6, nr 2/3(19/20), wiosna/lato 1998. Print.

7. Bartmiński J., Panasiuk J. Stereotypy językowe. [w:] Encyklopedia kultury polskiej XX wieku. Pod red. Jerzego Bartmińskiego. Wrocław, 1993, s. 366. Print.

8. Bartmiński, Jerzy (red.), 1980, Słownik ludowych stereotypów językowych. Zeszyt próbny, Wrocław: Wydawnictwo Uniwersytetu Wroclawskiego. Print.

9. Bartminski, Jerzy, 1986, Czym zajmuje siç etnolingwistyka? // Akcent. 1986. №26. S. 16-22. Print.

10. Bartmiński, Jerzy, 2012, Językowe podstawy obrazu świata, Lublin. Print.

11. Bartmiński, Jerzy. Nasi sąsiedzi w oczach stzdentów (Z badań nad stereotypami narodowymi) [w:] Narody i stereotypy. Pod red. T. Walas. Kraków, 1995. S. 259-260. Print.

12. Bartmin'skij, Ezhy. Stil kak znak. Deryvatsyonnaia kontseptsyia stylia. Yazykovoj obraz mira: ocherki po e'tnolingvistike (Language image of world). Perevod s pol'skogo. Indrik. Moskva. (2005): 320-342. Print.

13. Bartminskiy E. Yazykovoi obraz mira: ocherki po etnolynhvistike (Language image of the world: essays on ethnolinguistics): Moskva, 2005. Print.

14. Batsevych, Florii. Narysy z linhvistychnoi prahmatyky (Essays on linguistic pragmatics). Lviv, 2010. - $336 \mathrm{~s}$. Print.

15. Burak V. V. Subznakova fiksatsiia linhvokulturnoho zmistu v pokhidnykh nominatsiiakh rodychiv (na materiali ukrainskoi ta polskoi mov druhoi polovyny XIX stolittia) (Subsign fixation of linguistic and cultural content in the nominations of relatives (on the material of the Ukrainian and Polish languages of the second half of the nineteenth century). // Linhvistychni studii. Vyp. 34. - Donetsk. 2017., s.85-100. Print.

16. Chlebda, Wojcech. Sytereotypy jako jedność języka, myszlenia i działania. Stereotyp jako przedmiot lingwistyki : teoria, metodologia, analizy empiryczne .- Wrocław, 1998 [Wyświetl]. Strony: 31-41. Print.

17. Demiankov V. Z. Dominiruyushchye linhvisticheskie teorii v kontse XX veka (Dominant linguistic theories at the end of the twentieth century) // Yazyk i nauka kontsa XX veka: Sb. st. pod. red. Yu. S. Stepanova. Moskva., 1995. - 239-320 s. Print.

18. Doroszewski, Witold. Słownik Języka Polskiego. Warszawa: Wydaw. Naukowe PWN, 1997. Web.

19. Głaz Adam, 2015, Etnolingwistyka daleka i bliska, „Etnolingwistyka” 17, s. 7-20. Print.

20. Houlbrooke, Ralph. The English Family. Themes in British Social History. Personal education. New York. (2013): 265. Print.

21. Hromiak, Roman and Kovaliv, Yurii. Literaturoznavchyi slovnyk-dovidnyk (Literary dictionary-reference book). «Akademiya». Kyiv. (2007): 752. Print.

22. Hurford J. R., Heasley B. Semantics: a coursebook. Cambridge: Cambridge5University Press, 1983. Print. 
23. Ivanova S. V. Linhvokulturolohicheskiy aspekt issledovaniia yazykovykh edinits (Linguistic and cultural aspect of the study of language units). Ufa, 2003. - 367 s. Print.

24. Kardela, Henryk. Tak zwana gramatyka kognitywna a problem stereotypu. Etnolingwistyka, t. 1. 1988. Wyd. UMCS. Lublin. s. 42. Print.

25. Kiklewicz, Aleksandr. Pragmatyczne aspekty Językowego obrazu świata. [w:] Język. Komunikacja. Wiedza. Mińsk: Prawo i ekonomika, 2006. S. 319-339. Print.

26. Kognitywizm w świetle innych teorii, pod red. Olgi Sokołowskiej, Danuty Stanulewicz, Gdańsk. 2006, s. 209226. Print.

27. Konotacja semantyczna - strukturalistyczna czy kognitywna? // Językoznawstwo kognitywne III.

28. Konotacja: praca zbiorowa / pod red. Jerzego Bartmińskiego, Wzd. UMCS, Lublin, 1988., 202 s.

29. Krawczyk, Anna. Język żródłem wiedzy o człowieku. [w:] Etnolingwistyka, t.2. s. 29-38. Print.

30. Krysin L. P. Etnostereotipy v sovremennom yazykovom soznanii: $k$ postanovke problemy (Ethnostereotypes in modern linguistic consciousness: to the formulation of the problem) // Filosofskie $i$ linhvokulturolohicheskie problemy tolerantnosti. Ekaterynburh, 2003. Print.

31. Kubryakova, Elena. Nominativnyy aspekt rechevoy deyatel'nosty (Nominative aspect of speech activity). Moskva: Nauka, 1986., — 159 s. Print.

32. Kubryakova, Elena. "Evolyutziya Lingvisticheskih Idey vo Vtoroy Polovine XX veka (Evolution of linguistic ideas in the second half of the 20 th century)". Yazyk I Nauka kontsa XX veka (Language and science in the late 20 th century). Moskva: Rossiyskiy Gosudarstvennyy Universitet, 1995. Print.

33. Kubryakova, Elena. Tipy yazykovykh znacheniy (Language meanings tipes). Moskva: Nauka, 1981. Print.

34. Laionz Dzh. Linhvisticheskaia semantika: vvedenie (Linguistic semantics: introduction). Moskva., 2003., s. 111. Print.

35. Lakoff, Dzhordzh. Zhenshchiny, ogon' i opasnye veshchi: Chto katehorii yazyka hovoriat nam o myshlenii (Women, Fire, and Dangerous Things: What Categories Reveal About the Mind) / Per. $\mathrm{s}$ angl. Y.B. Shatunovskoho, Moskva: Yazyki slavianskoy kul'tury, 2004., c. 226. Print.

36. Lippman, Volt. Obshchestvennoe mnenye (Public opinion). - Moskva. 2004., 376 s. Print.

37. Lotman Yu.M. Struktura khudozhestvennoho teksta (Structure of artistic text). - Moskva., 1970. Print.

38. Morris Ch. Основание теории знаков (The basis of the theory of signs) // Semiotika. - Moskva., 1983., s. 37-89. Print.

39. Nechuy-Levyts'kyy, Ivan. Kaydasheva sim'ya; (Kaydash's Family). Kharkiv: Vesta: Ranok, 2003. Print.

40. Nycz, Ryszard. „Niepewna jasność" tekstu i „wierność" interpretacji... Czerwona serja, t. 15...s. 27-47. Print.

41. Peirce Ch. S. Lohika kak semiotika: teoriya znakov (Logic as semiotics: the theory of signs). // Metafizicheskie issledovaniya. Vyp. 11. 1999., s. 199-217. Print.

42. Pisarkowa K., Konotacja semantyczna nazw narodowości, „Zeszyty Prasoznawcze” 1976, №1, s.5-26. Print. 
43. Postovalova V. Y. Nauka o yazike v svete ideala tselnoho znaniya (The science of language in the light of the ideal of integral knowledge) // Yazyk i nauka kontsa XX veka. - Moskva., 1995. - 342-420 s. Print.

44. Prus Bolesław. Lalka. Wrocław: Zakład Narodowy im. Ossolińskich, 1991. Print.

45. Puzynina Jadwiga. Język wartości. Wyd. PWN. Warszawa, 1992., 264 s. Print.

46. Rozmowa z prof. Jerzym Bartmińskim, pod. red. Katarzyny Grzybowskiej. s.9. Print.

47. Rurawski, Józef: Władysław Reymont. Warszawa 1977, W. P ., s . 481. Print.

48. Sadokhyn A. P., Hrushevytskaia T. H. Etnolohiya (Ethnology). - Moskva., 2000. 304 s.

49. Schwarze Ch. Lexique et comprehension textuelle // Sonderfoshungbereich. Universitat Konstanz, 1985. № 112. P. 38-87. Print.

50. Selivanova O. O. Suchasna linhvistyka: napriamy ta problemy (Modern Linguistics: Directions and Problems). - Poltava., 2008. - 712 s. Print.

51. Semashko T. F. Stereotip kak frahment yazykovoi kartiny mira (Stereotype as a fragment of the language picture of the world). / Fylolohicheskie nauki, №2 (32). 2014., s. 176-179. Print.

52. Sienkiewicz, Henryk. Z pamiętnika poznańskiego nauczyciela. Wolne lektury. Web.

53. Skubalanka, Teresa. Wiersz Mickiewicza "Te rozkwitłe świeżo drzewa..." wśród konwencji stylistycznych epoki. Język Artystyczny 10. Śląsk. (1996): 53-60. Print.

54. Slavianskie drevnosti (Slavic antiquities). Etnolinhvisticheskiy slovar / pod obshchei red. N.Y. Tolstoho. Moskva., 1995-2008. T. 1-4. Print.

55. Sławkowa, Ewa. Instrumentarium badawcze współczesnego językoznawstwa w opisie semantyki tekstu artystycznego (wybór zagadnień). Cherwona serja, t. 15, pod red. A. Pajdzińskij I R. Tokarskiego. Lublin, Wyd. UMCS, 2001, s. 9-27. Print.

56. Słownik Języka Polskiego PWN // https://sjp.pwn.pl/. Web.

57. Sosiur, Ferdinan de. Kurs zahalnoi linhvistyky (Cours de linguistique generale): per. s fr. / Ferdinan de Sosiur ; Per. A. Korniichuk, K. Tyshchenko. - Kyiv., 1998 . - 324 s. Print.

58. Stereotypy językowe. [w:] Współczesny język polski. Encyklopedia kultury polskiej XX wieku, t. II, pod red. Jerzego Bartmińskiego. Wrocław. 1993, s. 375. Print.

59. Sternyn J. A. Leksicheskoe znachenie slova $v$ rechy (Lexical meaning of the word in speech). - Voronezh., 1985., 137 s. Print.

60. Svydnyts'kyy, Anatoliy. Lyuborats'ki. Kyiv: Znannya, 2016.- c. 98. Print.

61. Searle John R. Reference as a speech act. In: Searle, J. R, Speech Acts. An Essay in the Philosophy of Language. Chap. 4. Cambridge University Press, London, 1969, p. 77-96. Print.

62. Thackeray, William. Vanity Fair. Penguin Classics, 2003. Print.

63. Tokarski Ryszard, 2014, Światy za słowami. Wykłady z semantyki leksykalnej, Lublin.,371 s. Print. 
64. Tokarski Ryszard. Konotacja a problemy kategoryzacji. Język a kultura, t. 20. Wrocław., 2008. - 143-161 s. Print.

65. Tolstoi N. Y., Tolstaia S. M. Slavianskaia etnolynhvystyka: voprosy teorii (Slavic ethnolinguistics: questions of theory). Moskva., 2013. Print.

66. Vereshchahyn E.M., Kostomarov V.T. Yazyk i kultura (Language and culture). - M., 1983. 269 s. Print.

67. Vilinbakhova E. L. Linhvisticheskoe izuchenie stereotipov (Linguistic study of stereotypes). Sankt-Peterburg. 2015., 72 s. Print.

68. Vilinbakhova E. L. Stereotyp v lynhvystyke: obekt ili instrument issledovaniya? (Stereotype in linguistics: an object or research tool?) // Sbornik nauchnykh statei po materialam Pervoi konferentsii-shkoly «Problemy yazyka: vzghliad molodykh uchenykh». - M., 2012. - c. 19-28. Print.

69. Vitalii Zhaivoronok (red.), 2006, Znaky ukrainskoi etnokultury: Slovnyk-dovidnyk, Kyiv. Print. 